\title{
EFEKTIVITAS PENYULUHAN PENGENDALIAN KADAR GLUKOSA DARAH PASIEN DIABETES MELLITUS TIPE 2 MENGGUNAKAN METODE REMINDER DAN BOOKLET DI INSTALASI RAWAT JALAN RSUD A.W. SJAHRANIE
}

\author{
Dyera Wahyu Heraningtyas*, Jaka Fadraersada, Laode Rijai \\ Laboratorium Penelitian dan Pengembangan FARMAKA TROPIS \\ Fakultas Farmasi, Universitas Mulawarman, Samarinda, Kalimantan Timur \\ *email: heraningtyas@gmail.com
}

\begin{abstract}
ABSTRAK
Pengetahuan pasien tentang penyakit dan terapi DM memegang peranan penting dalam mengontrol kadar glukosa darah serta kepatuhan pasien dalam menjalankan terapinya. Tujuan penelitian ini untuk mengetahui pengaruh pemberian edukasi berupa booklet dan reminder terhadap kadar glukosa darah dan kepatuhan pasien DM tipe2 di Instalasi Rawat Jalan RSUD A. W. Sjahranie dibandingkan dengan kontrol. Penelitian dilakukan secara prospektif dengan metode eksperimen. Hasil penelitian berdasarkan umur paling banyak berusia 56-65 tahun dengan persentase pada sampel 43,33\% dan kontrol 46,67\%, berdasarkan jenis kelamin perempuan lebih banyak dibandingkan laki-laki yakni $60 \%$ pada sampel dan 56,67\% pada kontrol, berpendidikan SMA sampel 70\% dan kontrol 65\%, dan paling banyak berprofesi sebagai ibu rumah tangga dengan persentase pada sampel 55\% dan kontrol 51,67\%. Pada kelompok edukasi mayoritas pasien mengalami penurunan kadar glukosa darah tetapi hal ini tidak terjadi pada kelompok kontrol. Berdasarkan sisa obat (pill count) diperoleh kepatuhan pada kelompok edukasi 35 pasien $(58,33 \%)$ dan kelompok kontrol 12 pasien (20\%). 28 pasien dari 35 pasien yang patuh mengalami penurunan kadar glukosa darah sedangkan pada kelompok kontrol 10 pasien dari 12 pasien yang patuh mengalami penurunan kadar glukosa darah.
\end{abstract}

Kata Kunci : booklet dan reminder, diabetes mellitus, kepatuhan, pill count

\section{ABSTRACT}

Patient knowledge about the disease and therapy of DM holds important role to control the blood glucose levels and compliance in their therapy. The aims of this research were to know the influence in giving education like booklet \& reminder about the blood glucose levels and patient DM type II compliance in outpatient installation RSUD AWS and would be compared with control group. The research doing by prospective, design of research is experiment method. The result of this research from age get the most is 56-65 years old with presentence $43,33 \%$ in sample and 46,67\% in control, based gender get female is higher than male with $60 \%$ in sample and 56,67\% in control, based education get senior high school with $70 \%$ in sample and $65 \%$ in control and as housewife get 55\% in sample and 51,6\% in control. In the education group, the majority of patients experienced a decrease in blood glucose levels, but this did not occur in the control group. Based on the pill count obtained an adherence 
to an education group about 35 patients $(58,33 \%)$ and the control group of 12 patients (20\%). A total of 28 patients from 35 patients were adherent decreased of blood glucose levels, whereas in control group 10 patients from 12 patients were adherent decreased of blood glucose levels.

Keywords: booklet and reminder, complience, diabetes mellitus, pill count

\section{PENDAHULUAN}

Diabetes mellitus merupakan penyakit endokrin yang paling umum ditemukan. Penyakit ini ditandai oleh terjadinya hiperglikemia dan glikosuria. Ada beberapa jenis DM yaitu tipe 1, tipe 2, dan tipe gestasional. Diantara tipe DM yang ada, DM tipe 2 adalah jenis yang paling banyak ditemukan ( $\geq 90 \%$ ). DM tipe 2 adalah penyakit yang ditandai oleh kenaikan gula darah akibat penurunan sekresi insulin oleh sel beta pankreas atau gangguan fungsi insulin.

Faktor- faktor yang dapat menyebabkan penyakit DM aalah adanya faktor dari riwayat keluarga yang menderita DM, obesitas atau kegemukan, usia yang semakin bertambah, kurangnya aktivitas fisik, kecendrungan merokok, sering mengkonsumsi makanan berkolesterol tinggi, serta pada kehamilan. Komplikasi yang akan ditimbulkan antara lain gangguan penglihatan, penyakit jantung, gangguan ginjal, luka sulit sembuh dan membusuk (gangren), stroke dan sebagainya.

Jumlah penderita DM di Indonesia terus meningkat, berdasarkan data organisasi kesehatan dunia (WHO) menunjukan bahwa Indonesia merupakan Negara dengan penderita DM terbanyak ke empat di dunis setelah India, China, dan Amerika Serikat, dengan perkiraan penderita DM mencapai angka 21,3 juta orang pada tahun 2030.

Melihat bahwa DM dapat menyerang segala lapisan umur dan sosial ekonomi, serta akan memberikan dampak terhadap kualitas sumber daya manusia dan peningkatan biaya kesehatan yang cukup besar, maka diperlukan suatu program yang dapat mengendalikan kadar gula darah pasien DM. Salah satu program atau metode yang dapat digunakan untuk meningkatkan kepatuhan pasien DM adalah, pertama pasien DM harus memiliki pengetahuan atau pemahaman tentang terapi non farmakologi untuk pasien DM, seperti diet karbohidrat, mengurangi konsumsi makanan dan minuman yang manis, rutin berolahraga, dan membiasakan kebiasaan hidup yang sehat sehingga kadar gula darah pada pasien DM bisa dijaga agar tetap stabil dan tidak menimbulkan komplikasi lainnya. Selain itu,kepatuhan pasien dalam menjalankan terapi farmakologi juga dapat menunjang keberhasilan dalam pengobatan DM.

\section{METODE PENELITIAN}

Penelitian ini bersifat prospektif dan merupakan studi eksperimen dengan menggunakan pasien DM tipe 2 sebagai responden. Sampel akan dibagi kedalam dua kelompok, kelompok pertama akan diberikan edukasi berupa media booklet dan reminder, sedangkan kelompok kedua sebagai kontol yang tidak diberikan edukasi.

Kriteria inklusi adalah semua pasien DM tipe 2 yang aktif dan rutin mengikuti pemeriksaan di instalasi rawat jalan RSUD A.W. Sjahranie, berusia 20-65 tahun, memiliki data rekam medik, tidak dalam keadaan hamil, dan memiliki sarana untuk menerima layanan pesan pendek (SMS). Penelitian ini memiliki variabel berupa karakteristik, kepatuhan, serta profil kadar glukosa darah pasien DM tipe 2 yang diberikan edukasi reminder dan booklet, serta pasien DM tipe 2 yang tidak diberikan edukasi (kontrol). 


\section{HASIL DAN PEMBAHASAN}

1. Karakteristik Pasien

a. Gambaran Penderita Berdasarkan Jenis kelamin

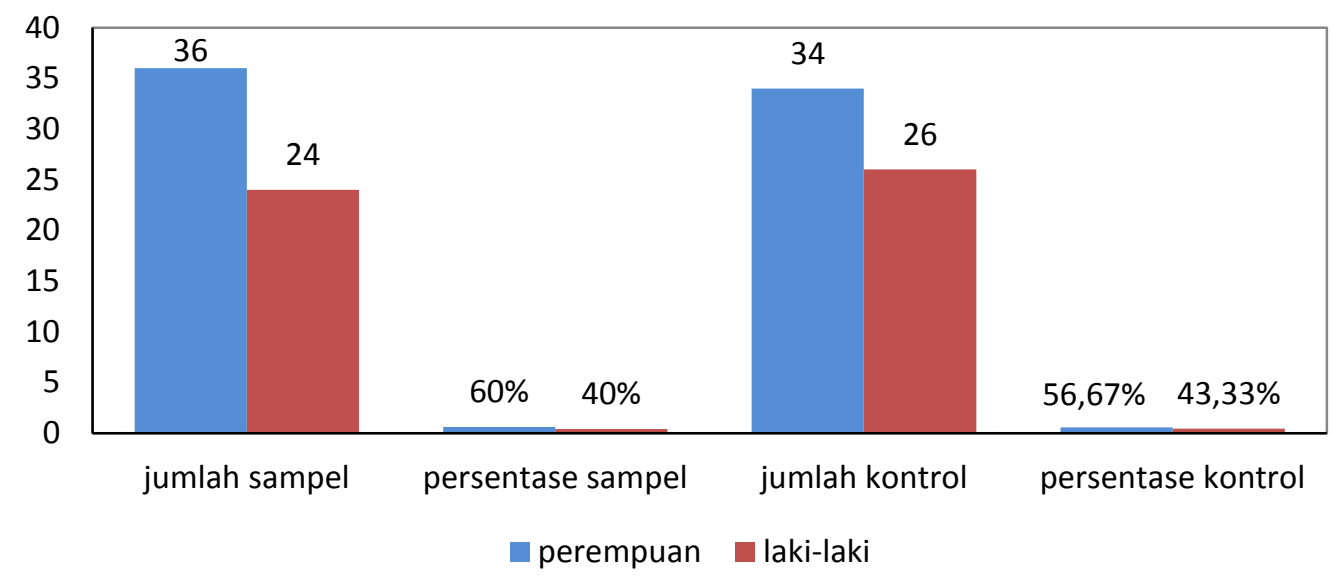

Gambar 1. Penderita berdasarkan jenis kelamin

Hasil yang diperoleh berdasarkan jenis kelamin pada pasien DM tipe 2 di instalasi rawat jalan RSUD A. W. Sjahranie banyak terjadi pada perempuan dibandingkan dengan laki- laki dengan persentase pada sampel sebanyak 60\% dan kontrol 56,67\%. Hal ini disebabkan karena pada perempuan memiliki kadar LDL yang lebih tinggi dibandingkan dengan laki-laki. Jumlah lemak pada laki-laki dewasa rata-rata berkisar antara 15-20\% dari berat badan total, dan pada perempuan sekitar 20-25\%. Sehingga faktor resiko terjadinya diabetes mellitus pada perempuan 3-7 kali lebih tinggi dibandingkan pada laki- laki yaitu 23 kali. Selain itu faktor sindroma siklus bulanan (premenstrual syndrom) dan pasca monopouse pada wanita dapat menyebabkan distribusi lemak di dalam tubuh menjadi mudah terakumulasi akibat proses hormonal tersebut sehingga wanita lebih beresiko menderita diabetes mellitus tipe 2 (Trisnawati, 2013).

b. Gambaran Penderita Berdasarkan Usia

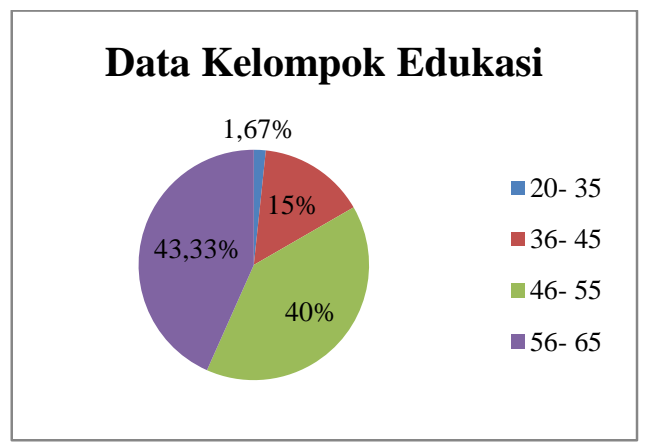

\section{Data Kelompok Kontrol}

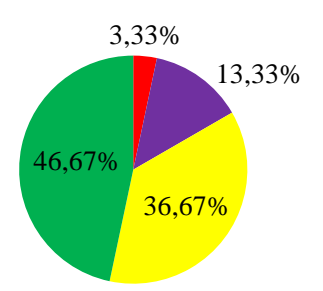

- 20- 35

- 36- 45

46- 55

- 56- 65

Gambar 2. Penderita berdasarkan usia 
Menurut DEPKES RI pembagian usia dikelompokan menjadi empat kategori yakni usia dewasa awal (20-35), usia dewasa akhir (36-45), usia lansia awal (46-55), dan usia lansia akhir (56-65). Hasil yang diperoleh pada data sampel maupun kontrol menunjukan usia responden yang paling banyak menderita diabetes mellitus adalah usia 56-65 tahun yang masuk dalam kategori usia lansia akhir. Peningkatan resiko diabetes seiring dengan umur, khususnya pada usia lebih dari 40 tahun, disebabkan karena pada usia tersebut mulai terjadi peningkatan intoleransi glukosa. Selain itu, semakin menuanya usia akan membuat kemampuan sel $\beta$ pankreas dalam memproduksi insulin menjadi menurun.

c. Gambaran Penderita Berdasarkan Pendidikan

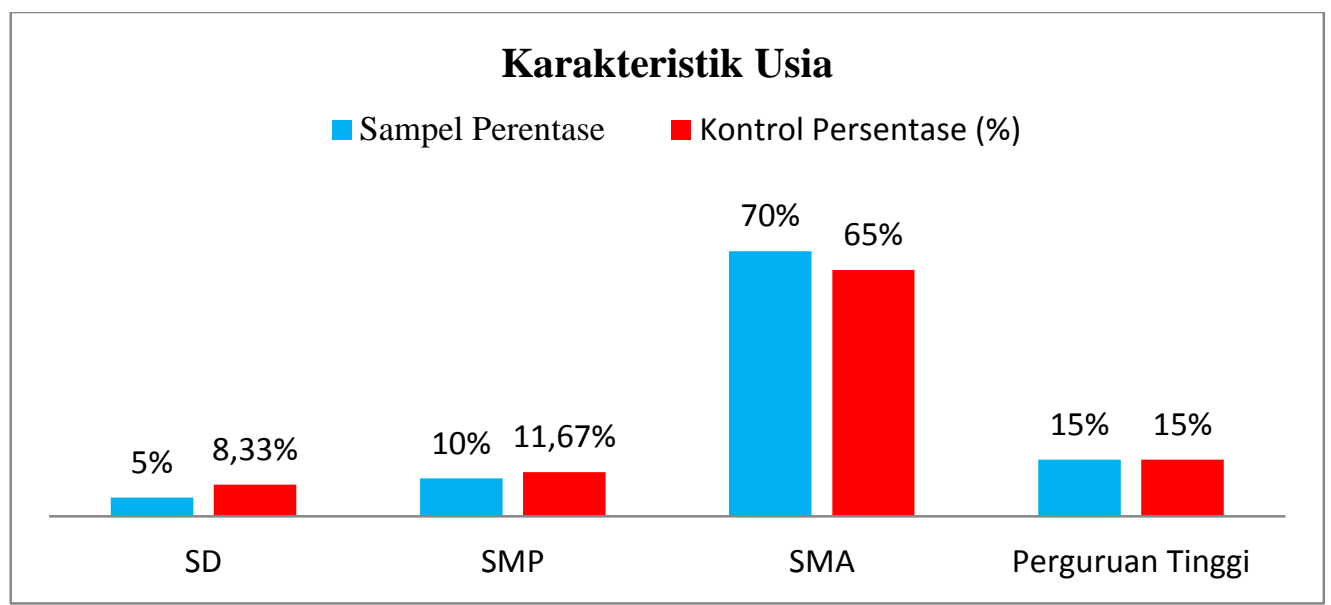

Gambar 3. Penderita berdasarkan pendidikan

Tingkat pendidikan memiliki pengaruh terhadap kejadian penyakit diabetes mellitus tipe 2. Orang yang tingkat pendidikannya tinggi biasanya akan memiliki banyak pengetahuan tentang kesehatan. Dengan adanya pengetahuan tersebut orang akan memiliki kesadaran dalam menjaga kesehatannya. Hasil penelitian yang diperoleh tidak sesuai dengan teori, pasien diabetes mellitus tipe 2 paling banyak diderita oleh pasien yang tamat pendidikan SMA, ini disebabkan karena orang yang memiliki pendidikan tinggi cenderung mengbaikan kesehatan dengan berbagai alasan, salah satunya berhubungan dengan pekerjaan dimana dengan adanya kesibukan yang tinggi menyebabkan kebiasaan hidup yang tidak teratur atau tidak teraturnya pola makan akan menyebabkan gangguan kesehatan. Menurut (Gibney, 2009) mengkonsumsi makanan yang rendah energi dan tinggi lemak selain aktifitas fisik yang rendah, akan mengubah keseimbangan energi dengan disimpannya energi sebagai lemak simpanan yang jarang digunakan. 
d. Gambaran Penderita Berdasarkan Pekerjaan

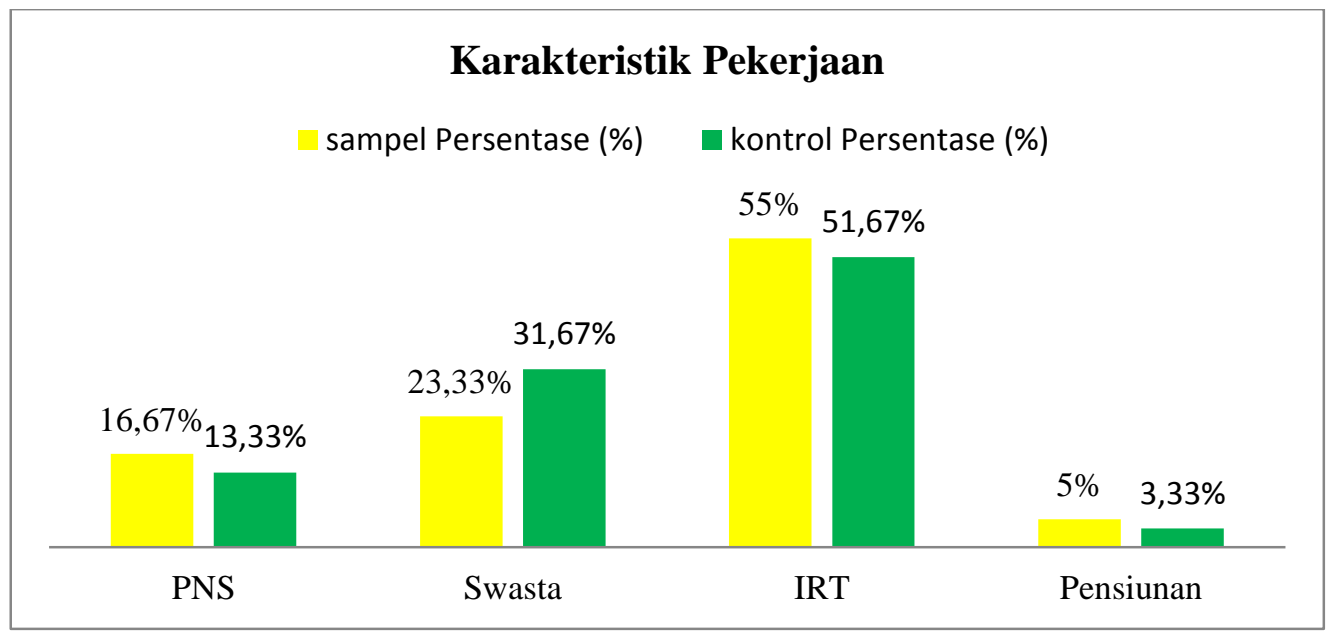

Gambar 4. Penderita berdasarkan pekerjaan

Jenis pekerjaan juga erat kaitannya dengan kejadian diabetes mellitus. Pekerjaan seseorang mempengaruhi tingkat aktivitas fisiknya. Hasil data yang diperoleh, sebagian besar responden adalah kelompok ibu rumah tangga dengan persentase pada kelompok sampel 55\% dan pada kelompok kontrol 51,67\%, hal ini bisa disebabkan karena aktivitas ibu rumah tangga yang cenderung berada dirumah tanpa melakukan aktivitas fisik yang terlalu banyak, sehingga resiko terkena diabetes semakin besar. Menurut (Ilyas, 2011), penyerapan glukosa oleh jaringan tubuh saat istirahat membutuhkan insulin, sedangkan pada otot yang aktif tidak disertai kenaikan kadar insulin walaupun kebutuhan glukosa meningkat. Hal ini dikarenakan pada waktu seseorang beraktivitas fisik, terjadi peningkatan kepekaan reseptor insulin di otot yang aktif. Masalah utama yang terjadi pada DM tipe 2 adalah terjadinya resistensi insulin yang menyebabkan glukosa tidak dapat masuk ke dalam sel. Saat seseorang melakukan aktivitas fisik, akan terjadi kontraksi otot yang pada akhirnya akan mempermudah glukosa masuk ke dalam sel. Hal tersebut berarti saat seseorang berkativitas fisik, akan menurunkan resistensi insulin dan pada akhirnya akan menurunkan kadar glukosa darah.

2. Profil Kadar Glukosa Darah Pasien DM Tipe 2

Tabel 1. Distribusi perubahan GD2PP pada kelompok yang mendapatkan edukasi reminder dan booklet.

\begin{tabular}{lcc}
\hline \multirow{1}{*}{ Jumlah Pasien } & \multicolumn{2}{c}{ Kadar gula darah } \\
\cline { 2 - 3 } & $\mathbf{2 0 0} \mathbf{~ m g / d L}$ & $<\mathbf{2 0 0} \mathbf{~ m g / d L}$ \\
\hline $\begin{array}{l}\text { Sebelum mendapatkan reminder } \\
\text { dan booklet }\end{array}$ & 43 & 17 \\
\hline $\begin{array}{l}\text { Sesudah mendapatkan reminder } \\
\text { dan booklet }\end{array}$ & 20 & 40 \\
\hline
\end{tabular}


Tabel 2. Distribusi perubahan GD2PP pada kelompok yang tidak mendapatkan edukasi reminder dan booklet (kontrol).

\begin{tabular}{|c|c|c|}
\hline \multirow{2}{*}{ Jumlah Pasien } & \multicolumn{2}{|c|}{ Kadar gula darah } \\
\hline & $\geq 200 \mathrm{mg} / \mathrm{dL}$ & $<200 \mathrm{mg} / \mathrm{dL}$ \\
\hline \multirow{2}{*}{$\begin{array}{l}\text { Tidak diberikan edukasi reminder dan } \\
\text { booklet (Kontrol) }\end{array}$} & 32 & 28 \\
\hline & 42 & 18 \\
\hline
\end{tabular}

Kadar glukosa darah digunakan sebagai parameter untuk mengetahui efektivitas edukasi yang diberikan kepada pasien DM tipe 2 di instalasi rawat jalan RSUD A. W. Sjahranie. Hasil penelitian menunjukan setelah pemberian edukasi reminder dan booklet terjadi penurunan jumlah pasien yang memiliki kadar glukosa darah diatas $200 \mathrm{mg} / \mathrm{dl}$ yakni dari 34 pasien menjadi 20 pasien, sedangkan pada kelompok kontrol terjadi peningkatan jumlah pasien yang memiliki kadar glukosa darah diatas $200 \mathrm{mg} / \mathrm{dl}$ sebanyak 42 pasien. Hal ini memberikan gambaran bahwa setelah pemberian edukasi pasien dapat menerapkan informasi yang ada dalam booklet dan reminder. Hal ini menunjukan bahwa semakin paham dan bertambahnya pengetahuan pasien diabetes tentang penyakitnya dapat membantu pasien tersebut dalam mengkontrol kadar glukosa darah karena pasien tahu mana yang harus dilakukan dan yang dihindari, sehingga pada kelompok yang diberikan edukasi berupa booklet dan reminder mengalami perubahan atau penurunan kadar glukosa darah. Menurut penelitian yang dilakukan oleh Sperl-Hillen pemberian edukasi secara individu lebih baik dalam meningkatkan kontrol glukosa darah pada pasien diabetes mellitus tipe 2 dibandingkan dengan edukasi secara kelompok maupun perawatan standar biasa (Pullen dan Vega, 2011). Berdasarkan penelitian (Alfian, 2014) pasien diabetes mellitus yang mendapatkan layanan pesan singkat dapat memberikan pengaruh terhadap kepatuhan pasien dan kontrol glukosa darah pasien diabetes mellitus tipe 2. Pemberian layanan pesan singkat pengingat (reminder) memiliki dampak positif menurunkan kadar glukosa darah secara signifikan pada pasien diabetes mellitus tipe 2, menurut (Antonie et al, 2014) yang menyimpulkan bahwa intervensi farmasis berpotensi meningkatkan kepatuhan terhadap pengobatan diabetes mellitus tipe 2 .

3. Profil Kepatuhan Pasien DM tipe 2 Berdasarkan Sisa Obat (pill count)

Tabel 3. Profil Kepatuhan Pasien DM tipe 2 Berdasarkan Sisa Obat (pill count)

\begin{tabular}{ccc}
\hline \multirow{2}{*}{ Variabel } & \multicolumn{2}{c}{ \% Kepatuhan konsumsi obat diabetik oral } \\
\cline { 2 - 3 } & Jumlah & Persentase (\%) \\
\hline Kelompok Edukasi : & 35 & $58,33 \%$ \\
$100 \%$ & 25 & $41,67 \%$ \\
$\leq 100 \%$ & & \\
\hline Kelompok Kontrol : & 12 & $20 \%$ \\
$100 \%$ & 48 & $80 \%$ \\
$\leq 100 \%$ &
\end{tabular}


Setiap pasien diabetes mellitus tipe 2 menerima obat antidiabetik oral yang dapat dilihat dari resep, lalu dicatat jumlah awal obat yang diterima pasien, setelah satu periode terapi yaitu selama satu bulan dilakukan perhitungan dengan metode pill count. Hasil yang diperoleh setelah pemberian perlakuan pada kelompok edukasi, terdapat 35 pasien yang patuh dalam mengkonsumsi obat diabetik oral, sedangkan pada kelompok kontrol hanya 12 pasien yang patuh mengkonsumsi obat diabetik oral. Ini disebabkan karena pada kelompok edukasi pasien menerima pesan singkat setiap harinya untuk mengingatkan waktu pasien untuk mengkonsumsi obat sehingga secara tidak langsung pasien mendapatkan kesadaran untuk mengikuti intruksi untuk mengkonsumsi obat, selain itu pasien pada kelompok edukasi juga mendapatkan media informasi berupa booklet, dimana dalam booklet tersebut dijelaskan mengenai pentingnya mematuhi terapi farmakologi bagi penderita diabetes, serta efek yang dapat ditimbulkan apabila obat diabetik oral tidak dikonsumsi dengan baik dan benar, sehingga pasien dapat menerapkan informasi yang diterima.

Kepatuhan pasien berdasarkan hasil pill count masih terdapat pasien yang kepatuhannya dibawah $50 \%$ hal ini bisa saja disebabkan oleh beberapa faktor. Menurut Rizka (2009), kepatuhan pasien dalam menjalankan terapi pengobatannya dipengaruhi oleh beberapa hal diantaranya, kompleksitas dari pengobatan, cara pemberian layanan, lamanya penyakit dan penyakitnya itu sendiri sangat berhubungan dengan kepatuhan pasien. Secara umum, semakin komplek pengobatanya, maka semakin kecil pasien akan mematuhinya. Indikator dari kompleksitas dari suatu pengobatan adalah frekuensi pengobatan yang harus dilakukan oleh pasien itu sendiri, misalnya frekuensi minum obat dalam sehari. Pasien akan lebih patuh pada dosis yang diberikan pada waktu satu kali sehari daripada dosis yang diberikan lebih sering, misalnya tiga kali sehari. Lamanya seorang pasien mengidap suatu penyakit tampaknya dapat memberikan efek negatif terhadap kepatuhan pasien. Makin lama pasien mengidap penyakit DM, makin kecil pasien tersebut patuh dalam pengobatannya.

4. Hubungan Antara Kepatuhan Pasien DM tipe 2 Dengan Kadar Glukosa Darah

Tabel 4. Data Kelompok Edukasi

\begin{tabular}{lccc}
\hline \multirow{2}{*}{$\begin{array}{c}\text { Tingkat Kepatuhan Minum } \\
\text { Obat Antidiabeik Oral }\end{array}$} & \multicolumn{3}{c}{ Kadar Glukosa Darah } \\
\cline { 2 - 4 } & Normal & Tinggi & Tetap \\
\hline Patuh : 35 pasien & 28 & 4 & 3 \\
Tidak Patuh : 25 pasien & 6 & 16 & 3 \\
\hline
\end{tabular}

Tabel 5. Data Kelompok Kontrol

\begin{tabular}{lccc}
\hline \multirow{2}{*}{$\begin{array}{c}\text { Tingkat Kepatuhan Minum } \\
\text { Obat Antidiabeik Oral }\end{array}$} & \multicolumn{3}{c}{ Kadar Glukosa Darah } \\
\cline { 2 - 4 } & Normal & Tinggi & Tetap \\
\hline Patuh : 12 pasien & 10 & - & 2 \\
Tidak Patuh : 48 pasien & 5 & 42 & 1 \\
\hline
\end{tabular}


Salah satu faktor yang berhubungan dengan pengendalian kadar glukosa darah adalah faktor kepatuhan pasien dalam mengkonsumsi obat antidiabetik oral. Kepatuhan pengobatan adalah keterlibatan secara aktif dan sukarela dari pasien terhadap pengelolahan penyakit yang dideritanya dengan mengikuti kesepakatan pengobatan yang telah dibuat antara pasien dan petugas kesehatan. Hasil penelitian yang diperoleh menunjukan pada kelompok edukasi dari 60 pasien terdapat 35 pasien yang patuh dalam mengkonsumsi obat antidiabetik oral. Dari 35 pasien yang patuh tersebut terdapat 28 pasien yang menunjukan penurunan kadar glukosa darah. Sedangkan pada kelompok kontrol dari 60 pasien hanya terdapat 12 pasien yang patuh dan dari 12 pasien yang patuh hanya 10 pasien yang mengalami penurunan kadar glukosa darah. Pengetahuan merupakan faktor yang sangat penting dalam pembentukkan perilaku seseorang. Perilaku yang didasari oleh pengetahuan akan bertahan lebih lama dibandingkan dengan perilaku yang tidak didasarai oleh pengetahuan. Penderita DM tipe 2 yang memperoleh edukasi sehingga pengetahuannya meningkat memiliki kemampuan adaptasi dan melakukan perubahan perilaku yang lebih baik. Semakin baik pengetahuan penderita mengenai kondisi yang dialaminya, semakin baik pengendalian kadar glukosa darah yang dapat dicapai. Menurut (Alfian, 2015) pasien yang patuh hanya karena perintah dari dokter merupakan kepatuhan yang sangat tidak diharapkan, melainkan kepatuhan yang timbul atas kesadaran diri sendiri pasien yang sering disebut dengan istilah adherence. Kepatuhan adherence memiliki arti bahwa pasien paham akan penyakit diabetes mellitus yang dialaminya dan mengerti akan pengobatan diabetes mellitus yang harus dilakukan terus-menerus agar terkontrolnya kadar glukosa darah pasien tersebut, oleh karena itu kepatuhan sangat erat hubungannya dengan kadar glukosa darah, semakin tinggi tingkat kepatuhan pasien maka kadar glukosa darah akan turun, sebaliknya semakin rendah kepatuhan minum obat pasien maka kadar glukosa darah tidak dapat terkontrol yang artinya kadar glukosa darah akan tetap tinggi.

Terkait dengan hasil penelitian kadar glukosa darah pasien DM tipe 2 di instalasi rawat jalan RSUD A. W. Sjahranie, tidak semua responden penelitian yang mendapatkan edukasi mengalami peningkatan kepatuhan dan penurunan kadar glukosa darah. Pada kelompok edukasi dari 60 pasien terdapat 25 pasien yang tidak patuh dengan peningkatan kadar glukosa darah sebanyak 16 pasien. Sedangkan pada kelompok kontrol dari 60 pasien terdapat 48 pasien yang tidak patuh dengan peningkatan kadar glukosa darah sebanyak 45 pasien. Selain faktor kepatuhan dalam mengkonsumsi obat antidiabetik oral, ada beberapa faktor yang juga dapat mempengaruhi kadar glukosa darah pasien diabetes mellitus tipe 2, diantaranya adalah perubahan gaya hidup (pola makan dan tingkat aktifitas), kepatuhan diet asupan makanan (karbohidrat, protein, lemak dan serat), aktifitas fisik, dan pengetahuan penderita DM mengenai penyakit yang diderita.

\section{KESIMPULAN}

1. Karakteristik pasien diabetes mellitus tipe 2 yang menjadi subjek penelitian di RSUD A. W. Sjahranie periode 2015-2016 adalah 60\% perempuan pada kelompok edukasi dan $34 \%$ pada kelompok kontrol, berusia rata-rata 56-65 tahun dengan persentase pada kelompok edukasi 43,33\% dan pada kelompok kontrol 46,67\%, berpendidikan SMA dengan persentase pada kelompok edukasi 70\% dan kelompok kontrol 51,67\% serta 
berprofesi sebagai ibu rumah tangga sebanyak 55\% pada kelompok edukasi dan 51,67\% pada kelompok kontrol.

2. Terdapat penurunan jumlah pasien dengan kadar glukosa darah $\geq 200 \mathrm{mg} / \mathrm{dl}$ setelah mendapatkan edukasi. Sedangkan pada kelompok kontrol terjadi peningkatan jumlah pasien dengan kadar glukosa $\geq 200 \mathrm{mg} / \mathrm{dl}$.

3. Persen kepatuhan pasien dalam mengkonsumsi obat antidiabetik oral meningkat pada kelompok pasien DM tipe 2 yang mendapatkan edukasi booklet dan reminder.

4. Terdapat keterkaitan antara tingkat kepatuhan pasien dengan kadar glukosa darah pasien DM tipe 2, dimana 28 pasien dari 35 pasien yang patuh mengalami penurunan kadar glukosa darah (terkontrol). Sedangkan pada kelompok kontrol terjadi peningkatan jumlah pasien yang memiliki kadar glukosa darah yang tidak terkontrol.

\section{SARAN}

Perlu dilakukanya pemberian informasi kepada setiap penderita diabetes mellitus yang dilakukan oleh tenaga kesehatan yang bertujuan untuk menambah informasi dan motivasi kepada pasien diabetes mellitus. Selain itu, perlu dilakukan penelitian lanjutan dengan jangka waktu pemantauan yang lebih lama dengan menggunakan desain studi yang berbeda, menggunakan indikator pengendalian kadar glukosa darah yang lebih lengkap, misalnya menyertakan data kadar HbAlc agar diperleh hasil yang sangat akurat.

\section{DAFTAR PUSTAKA}

Alfian, R. 2014. Layanan Pesan Singkat Pengingat untuk Meningkatkan Kepatuhan dan Menurunkan Tekanan Darah Pasien Hipertensi Di RSUD. Dr. H. Moch. Ansari Saleh Banjarmasin, Jurnal Media Farmasi, 11(2).

American Diabetes Association. 2015. Standards Of Medical Care IN Diabetes-2015, Diabetes Care., 38(1): S01-S94.

Gibney .M. J. 2009. Gizi Kesehatan Masyarakat. Jakarta: EGC.

Ilyas, E. I. 2011. Olahraga bagi Diabetesi dalam:. Penatalaksanaan Diabetes Melitus Terpadu bagi dokter maupun edukator diabetes. Jakarta: Fakultas Kedokteran Universitas Indonesia.

Jelantik. 2014. Hubungan Faktor Resiko Umur, Jenis Kelamin, Kegemukan, dan Hipertensi Dengan Kejadian DM Tipe 2 Di Wilayah Kerja Puskesmas Mataram. Jurnal Media Bina Ilmiah. Vol 8, No 1, Tahun 2014.

Trisnawati Shara K,. 2013 . Faktor Resiko Kejadian Diabetes Mellitus Tipe 2 di Puskesmas Kecamatan Cengkareng Jakarta Barat Tahun 2012. Jurnal Ilmiah Kesehatan Vol.5 No.1 Januari 2013.

Witasari, Ucik dkk. 2013. Hubungan Tingkat Pengetahuan, Asupan Karbohidrat dan Serat Dengan Pengendalian Kadar Glukosa Darah Pada Penderita Diabetes Mellitus Tipe 2. Jurnal Penelitian Sains \& Teknologi, 10: $130-138$.

Vervloet, et all. 2012. SMS Reminders Improve Adherence To Oral Medication In Type 2 Diabetes Patients Who Are Real Time Electronically Monitored, IJMI: 81(9), 594604. 